\title{
Retakaful From Syariah Perspective: A Comparative Study
}

\author{
Setiyawan Gunardi, Nurdeng Deuraseh \\ Universiti Putra Malaysia, Serdang, Selangor, Malaysia \\ Hailani Muji Tahir, Sanep Ahmad \\ Universiti Kebangsaan Malaysia, Bangi, Selangor, Malaysia
}

\begin{abstract}
Retakaful is an arrangement to risk of retention limit funding takaful. Similarly, risk arrangements are operated by reinsurance to insurance funding. But, how is the retakaful legal status in Islamic law and the differences between reinsurance. The objective of this study is to identify the status of the retakaful in Islamic law and identify the differences between reinsurance. The study to found that retakaful is prescribed and an alternative to reinsurance, as well as a method of financial protection against the various risks of the takaful industry in excess of the retention limit, which may occur at any time in accordance with the principles of Sharia. Also in this method of risk arrangements, It is found that there are very significant differences in risk between retakaful and conventional reinsurance.
\end{abstract}

Keywords: retakaful, risk, retention limits, reinsurance

\section{Introduction}

Islamic Financial System (IFS) is one of the areas most needed to conduct business in accordance with sharia foundation. This growth is rising rapidly and the speed has even managed to expanding the number of financial institutions, products and services, financial performance, and infrastructure support. One of IFS operations are being pursued is a retakaful sector in the takaful industry.

Retakaful viewed from an Islamic perspective, it is a new type of contract, which has not been developed and researched at times of ijtihad through previous ijtihad. Retakaful mechanism at this time has created and raised the Muslim scholars to study and discuss legal position of retakaful. The concept of retakaful required to play an important role in addressing the problems does face the takaful industry. Retakaful is the importance of urgently needed in developing takaful operations against the risks of loss faced by the takaful industry. Thus, the takaful services, facilities of retakaful are very important as a vehicle for generating growth and development of takaful operations in overall (Yusof, 2006, p. 115).

Setiyawan Gunardi, Ph.D., Post-Doctoral Fellow, Halal Products Research Institute, Universiti Putra Malaysia.

Nurdeng Deuraseh, Associate Professor, Head, Laboratory of Halal Policy and Management, Halal Product Research Institute, Universiti Putra Malaysia.

Hailani Muji Tahir, Professor, Faculty of Islamic Studies, Universiti Kebangsaan Malaysia.

Sanep Ahmad, Associate Professor, Faculty of Economic and Management, Universiti Kebangsaan Malaysia.

Correspondence concerning this article should be addressed to Setiyawan Gunardi, Institut Penyelidikan Produk Halal, Universiti Putra Malaysia, Putra Infoport, 43400 UPM Serdang, Selangor Darul Ehsan, Malaysia. E-mail: setiyawan99@yahoo.com; setiyawan@upm.edu.my. 


\section{Meaning of Reinsurance and Retakaful}

To get a glimpse of reinsurance and retakaful, the author will present this study as a prelude meaning as follows.

\section{Reinsurance}

Prof Dr. al-Qurrahdagi (2005, p. 425) says:

Reinsurance is the agreement between the insurance company and reinsurance company assumes the risk of loss for the period, for which the charge imposed on insurance companies, aiming to get a reply/damage by taking part of the payment rate of insurance premiums. (Sharafuddin, 1983, pp. 85-86)

Cockerell (n.d.) says:

Reinsurance is a system where by the insurance who deal with the insuring public ceded all or part of an insurance to other insurers known as reinsurer. In other words, the ceding company pays to the reinsurers, thereupon agree to reimburse to the ceding company the claims (or an agreed proportion of them) which the ceding company may find itself liable to pay under the original insurance. (p. 139)

Based on the above meanings, find that reinsurance is reinsurance practices made by insurance operators to reinsurers through a business contract. Insurance operators insure the risks are transferring either in part or in whole, to reinsurers with premium payments. This means the risk borne by the reinsurance company through premium payments. At the same time, the insurance operators hope to be compensated in the event of a claim resulting. If barring any sort of a risk, then the premium fee will belong reinsurance company entirely.

Figure 1 shows a system of reinsurance mechanism. Insurance operators transfer (the arrow) the risk of great value insurance products (risk A, risk B, risk C, risk D) as insurance for bungalows, airplanes, ships, and cars to reinsurers. These risks are managed by the insurance operators, whether from individuals or companies. Insurance operator governs risks by the reinsurance way to reinsurance losses by the insurance products of part or all of the risk to reinsurers. So, the risk of loss and destruction pose will be borne by reinsurance companies.

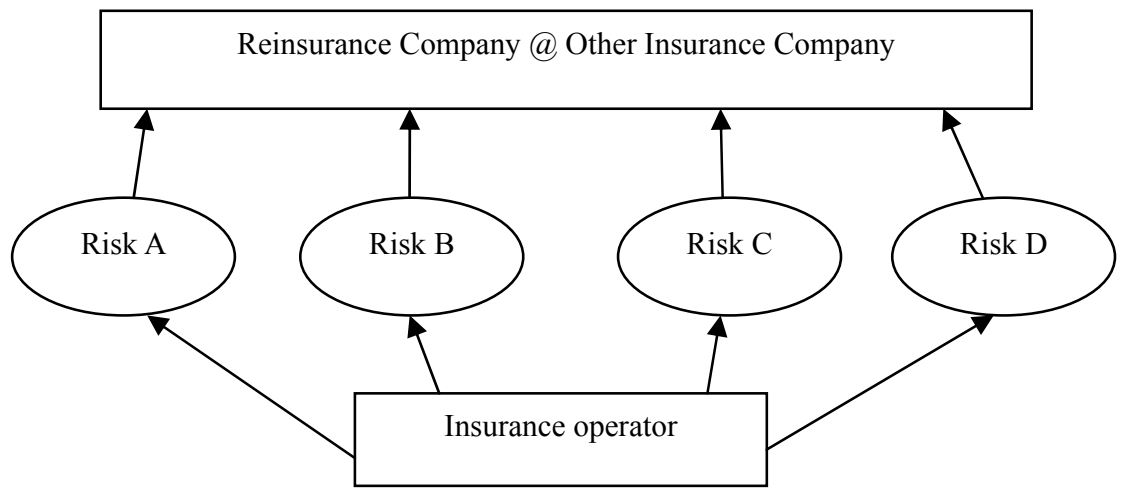

Figure 1. Risk transfer in conventional reinsurance mechanism.

\section{Retakaful}

Sula (2004) defined retakaful as a mutual process between a bear session (ceding company) or takaful operator with reinsurer (reinsurer or retakaful company), where there is mutual consent process (mutually agree) risks and requirements set forth in contract. In the operation, using the principles of sharia, free of gharar, maysir, and riba. In a book "Takaful Basic Guide" (IBFIM, 2009, p. 102) described the meaning of retakaful is one of risk management tools used by the takaful operator to share part of the risk in the fund to the takaful 
operator or other retakaful company. The amount of risk borne by the takaful funds for its own account called the retention limit.

Based on the meaning of the term, then found that retakaful is a takaful company that processing retakaful mechanism of risk in a given time, whether in part or whole to retakaful company or other takaful companies to share the risks are too great loss suffered takaful operators at a time by using the conditions in line with the principles of Sharia.

Figure 2 shows that the practice of sharing risk (arrows) in the course of retakaful mechanism. Takaful operator shares the risks of a substantial value loss (risk A, risk B, risk C, and risk D) as takaful risk for bungalows, takaful risk for ships, takaful risk for planes, and the risk of cars between other takaful operators. Through its retakaful, takaful risks have high value products can be borne jointly between the participants of retakaful/takaful operators. The takaful operator will feel lighter load to bear the liability to indemnify each other together than the takaful operator bear alone. Related to these parties in the retakaful mechanism will cooperate, mutual responsibility and mutual cover-bear-protect each other against risks either all risks, and in part of them, the high value of takaful products can be protected.

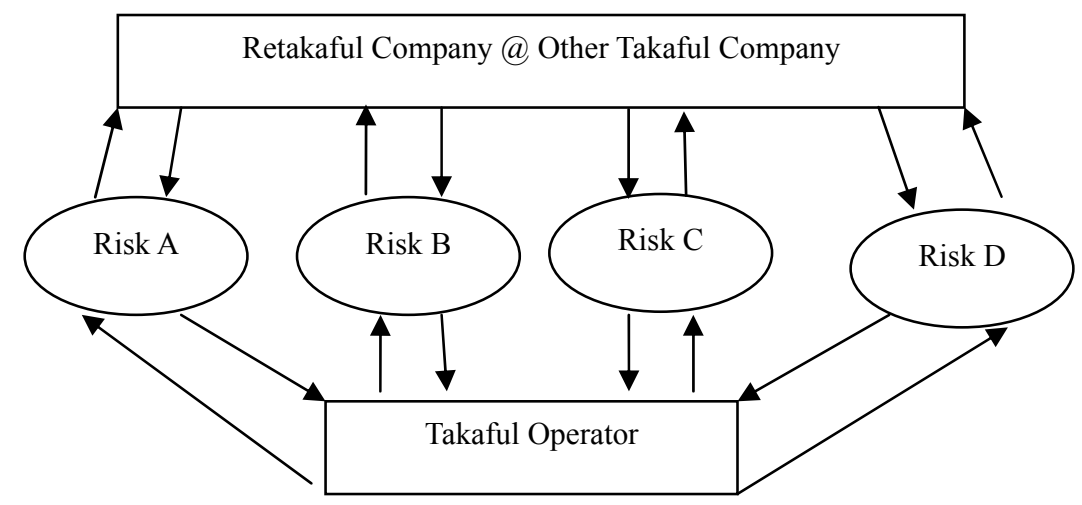

Figure 2. Risk share in retakaful mechanism.

\section{Methods of Retakaful}

Retakaful method of arranging a too big risk is not much difference with the method of reinsurance. However, the intake should be revised method retakaful then updated so that it is aligned with retakaful mechanism that leads to risk sharing. This retakaful method is as follows.

\section{Facultative}

Facultative refers to the method of retakaful arrangements involving the transfer of risk from the takaful operator to retakaful company based on the risk for the risk (case by case). Under facultative retakaful, each risk considered separately and each of the parties involved are free to decide whether to cede (on behalf of the takaful operator) or accept/reject (for the retakaful company) risk being considered. This means that when the takaful operator receives an application for takaful has value exceeds the retention limit, it can consider the risks exceed the retention limit, case by case basis, whether it is to cede risk to retakaful company or not. At the same time, the retakaful company, it was also entitled to consider the risks proposed by the takaful operator case by case basis whether they want to accept or reject the risk. If takaful operators want to cede risk retention limit successfully identify retakaful company might be willing to accept the risk, both takaful and retakaful company will sign a legal contract in relation to facultative retakaful. 
With regards to the meaning of facultative means to transfer risk refers to conventional reinsurance. This risk transfer mechanisms against retakaful concept. Practice of retakaful refers to the method that brings meaning to risk sharing, because this mechanism in line with Islamic principles.

\section{Treaty}

Treaty retakaful refers to retakaful where all the risks fulfill the requirements of the treaty (agreement) will get takaful coverage from retakaful company automatically. Under treaty retakaful, an agreement will be signed by the takaful and retakaful company. In the agreement signed, all terms and provisions in relation to the risk will be transferred to the retakaful company stated clearly. If the risk was underwritten by takaful operators to fulfill the provisions set forth in the agreement, this risk will automatically be transferred and assumed by the retakaful company. In other words, this means that the takaful operator must cede all risks and fulfill the requirements of the agreement that has been signed and retakaful company must also accept the risk automatically without any further discussion with the takaful operator. Takaful operators may not make the selection of the risk to be ceded to retakaful company and retakaful company also may not rule out the risk of retakaful protection that meets the conditions and provisions set forth in the agreement was signed.

As the treaty is retakaful arrangements on large risks, then this method still refers to the original principles of retakaful which means to share risk, and not to transfer risk as reinsurance practice because it does not conform to sharia principles. However, there is also the meaning of the treaty on sharing risk as defined in the four types of treaties. Into four types of treaties retakaful in the quota share treaty, surplus treaties, excess of loss treaty and stop loss treaties.

Quota share treaty in any takaful operator and retakaful company agreed to share contribution payment and loss of all takaful business was underwritten by the takaful operator at a predetermined rate up to a maximum amount that was agreed upon by them. Retention limit should be borne by the takaful operator expressed as a percentage, it is not expressed in absolute values (pro rata).

Surplus treaties, retakaful company agrees to accept cessions in excess of the retention limit up takaful operators to set a maximum amount. Takaful operator and retakaful company then share contribution payments and losses according to a certain ratio based on the takaful business to their respective, relative to the face value of takaful underwritten. It was carried out on line.

Excess of loss treaty is commonly used by takaful operators to obtain protection against very large losses. Under this treaty, retakaful company will incur losses in excess of the retention limit takaful operators up to a specified maximum amount.

Stop loss treaty is the takaful operator set percentage of losses incurred, while the percentage is willing to be handed over to the retakaful company. Usually, the amount of damages will to be collected for a period of one year. It is also known as the aggregate excess of loss.

Four types of treaties can be categorized into two, namely, proportional treaty ${ }^{1}$ and non-proportional treaties. ${ }^{2}$ The first and second types are of treaties the category in which the loss is proportional treaties,

\footnotetext{
${ }^{1}$ Proportional treaty is arrangements of retakaful when takaful operator and retakaful company share contributions and claims related to the original contract of takaful in the same proportion as the original of takaful which was submitted by takaful operator and was acquired by retakaful company.

${ }^{2}$ Retakaful not proportional is retakaful arrangements when takaful operators bear the payment for all losses up to the amount agreed upon in advance. Balance of any loss in excess of agreed limits will be borne by the retakaful company, often as the maximum contractual amount.
} 
contributions and expenses shared between the takaful operator and retakaful company rata basis. While the third and fourth treaty is under the category of non-proportional treaties. Under this category, simply retakaful company will fund the claim after the expiry of takaful operators use protective provisions (Muhammad, Redzuan, \& Said, 1995, p. 117).

Treaty under retakaful is usually signed by the takaful products. If the product is fire takaful then any property covered under this scheme will be put under fire retakaful where the recipient automatically receives a bid of acceptance of retakaful from the giver company without choosing the risks that require only. In other words, any fire takaful scheme participation by the takaful operator will be covered by the automatic re-takaful company (Yusof, 1996, p. 118).

There are also retakaful managed by the participants. In this case, the lender will first determine the ability of the takaful funds it managed to bear part of the amount protected on the protected property. Any amount exceeding this limit will be submitted to the retakaful, if agreed upon by the recipient company/retakaful. The giver company will pay the contribution of takaful to the recipient company and in return, the recipient company agreed to provide retakaful. This contribution is actually money of takaful contributions paid by the original participants to the giver company.

\section{The Legality of Retakaful/Reinsurance}

Implementation of the retakaful concept also prescribed in Islamic law, as the takaful concept underlying the exercise of retakaful. Many evidences support the legality, although there are not nas (Islamic texts). Yet it is the result of Istinbat from evidences that will facilitate the understanding the concept of retakaful. Even so the legality also in accordance with the existing legislation in the Act of takaful is subject to national carry out takaful and retakaful. During the act does not conflict with Islamic texts, mechanism of retakaful is permissible and legal should be carried out in the takaful industry.

In Islam teaching, the main source of reference is the law of the Quran in the course of all things. Retakaful in the takaful industry is one of the business transactions, which must refer to it. Reference source of this law can be seen in Surah Ali CImran verse 37, which means: "Right graciously did her god accept her: he made her grow in purity and beauty: to the care of Zakariya was she assigned. every time that he entered (her) chamber to see her, he found her supplied with sustenance". He said: "O Maryam! whence (comes) this to you?" she said: "From Allah. for Allah Provides sustenance to whom He pleases without measure".

This sentence contains a word "wakaffalaha Zakariya" that signifies handed to be preserved by the Prophet Zakariya. Prophet Zakariya, which was to preserve and take care of Maryam. al-Qurtubiy in his tafsir, said: "wakaffalaha Zakariya" that is "damanaha ilayh" which means guarantee, Abu CUbaydah felt daman al-qiyam biha which means the warranty is done with it. While Kufiyyun gave meaning as mulazamah to preserve and guaranteed Maryam with all his ability and made smooth (al-Qurtubi, 2000, pp. 45-46). The concept of maintenance and bail-guarantee is also the core of the concept of retakaful, where the takaful operators alike other takaful operators under the governance of retakaful company to preserve and guarantee each other.

The arguments referred to in the hadith as the second main source of law in general indicates that the principle of transactions, particularly through the sector of retakaful. Although this hadith does not state directly to retakaful purposes, it is pointed to a practice in muamalah. Hadith related to retakaful mechanism is meaning "Abu Musa (may Allah be pleased with him/radiyallah anh)". The messenger of Allah (s.a.w) said: 
"A believer (mu'min) to another believer that as a building where every part of the building to strengthen other parts"3. This hadith explains the importance of one component with the other components to be a building. Beginning made a foundation, frame, wall, thus creating a building. However, if a component is not perfect, then the building will not be strong, but do not look beautiful to look at. Similarly, the concept and mechanism of retakaful as a building shaped through the role of the takaful operator. Retakaful mechanism could only be realized through the role of the takaful operator. The role of takaful operators giving contributions will strengthen the financial system of retakaful funds are stronger. Instrument funds contributions to fund welfare. Then takaful funding will be allocated to the takaful operators face a risk of loss.

Retakaful mechanism is one of the areas of transactions (muamalah), or, the legality reinforced through method of fiqh ( qwa $^{c}$ id fiqqiyyah) that addresses the transactions, as described by al-Suyuti (1998) and Nyazee (2004, p. 34). Method of fiqh is al-Asl fi al-Mu'amalat al-Ibahah hatta yadulla al-Dalil al al-Tahrim. Meaning: The original rule for all things is permissibility, unless specifically prohibited by shariah. This method explains permissible of the various transactions, in various sectors throughout it does not conflict with the law prohibiting it. Similarly retakaful sector is one of the areas of transactions, which should be permissibility.

Retakaful concept at the time of the Prophet (peace be upon him) in practice is described in the books of fiqh and Islamic history. There are some practices that reflect the mechanism of retakaful. In Sirah of Ibn Hisham, retakaful mechanism envisioned by the people of muhajirin. Clan of Muhajirin from the Quraish still have them of their rights and receive the same boat one rice ransom blood (blood money/diat) to each other (because of manslaughter involuntary) with good way and fair among believers. Bani of ${ }^{\mathrm{C}}$ Awf from Yathrib still have their rights, responsibilities to bear away the ransom they pay each family together with good ransom and fairly among those who believe (Salamon, 1989, p. 224).

Meaning of blood money is damages paid by the killer to groups or families of those killed. Actually killer must pay damages but the group took over to pay for the killer to be a member. In pagan times, payment imposed on the murderer is 10 female camels. Abd al-Muttalib redeems his son, Abdullah to sacrifice 10 female camels and he had to repeat the sacrifice of 10 times. Surely this is a good custom to replace the diat bloody revenge in order to avoid the occurrence of bloodshed. From here arose diat to make camel as spare parts for the loss of life. It can ease the fire of war and lead to reconciliation between the two parties in dispute with the wounds suffered by the two parties (Muslihuddin, 1989, pp. 19-21).

Meanwhile, in the books of fiqh there is a system of protection or social security schemes that guarantee well-being a member of a community that has been implemented by the Prophet (peace be upon him). Scheme of al-Aqilah is a scheme introduced by the Messenger of Allah, as soon as he moved to Medina and unite the immigrants/muhajirin and the Ansar. According to this system that each member either Ansar or immigrants to hold joint financial fund to be known as al-Kanz. The purpose of the fund is to provide assistance to any member involved with manslaughter involuntary and liberate the captives.

Majma $^{c}$ al-Fiqh al-Islami makes Islamic seminar held its second session in Jeddah, Saudi Arabia, from 10 until 17 Rabic al-Thani 1406H (Islamic calender) corresponding to 22 until 28 December 1985. Accompanied by the Islamic scholars to discuss and study a topic: al-Ta'min wa I' adat al-Ta'min (insurance and reinsurance),

\footnotetext{
${ }^{3}$ al-Bukhāri, Sahih al-Bukhāri, kitāb al-adab, bāb ta ${ }^{c} \bar{a} w u n$ al-mu'minin ba ${ }^{c}$ duhum ba ${ }^{c}$ dan, no. 5680; Muslim, Sahih Muslim, kitāb al-birr wa al-sillah wa al-ādāb, bāb tarāhum al-mu'minin wa ta ${ }^{\mathrm{c}} \bar{a} t u f i$ ìm wa ta ${ }^{\mathrm{c}} \bar{a} d u d i h i m$, no. 2585; al-Turmudhi, Sunan al-Turmudhi, kitāb al-birr wa al-sillah ' ${ }^{\text {an }}$ rasūl Allah (s.a.w), bāb mā'a jā’a fi shafaqah al-muslim calā al-muslim, no. 1928.
} 
having argued earlier studies, deepen the study of the form, and the types, principles are the used and the goal is intended, after looking at the sources of fiqh and gathering Majma ${ }^{c}$ of fiqh on this. Then stated that: First: Contract of commercial insurance managed by the companies is contained elements of fraud and contract is canceled. Thus, the ruling is unlawful in Islamic law. Second: Contract of parts that can be referred to the principles of Islamic transaction is $t a^{c}$ awun insurance contract that is based on $t a b a r r u^{c}$ (contribution/donation) and $t^{c}$ awun (helping each other/cooperation), this is also attributed to the reinsurance made on the basis of insurance of $\mathrm{ta}^{c}$ awun. Third: The call to Muslim countries to establish institution/ $\mathrm{ta}^{c}$ awun insurance companies, as well as the companies work together to establish an Islamic reinsurance company, so Islamic economics is protected from the elements of usury and contradictions of to annoy Allah rules over these people (al-Salus, 1998, pp. 501-502).

Based on this study, it found that the concept of retakaful in the industry of takaful is prescribed. Islamic evidences are a fundamental building to implement this concept of retakaful in the takaful industry body, so that it is aligned with Islamic law.

While the reference for source law of reinsurance, according to Golding (n.d.) explains:

A Reinsurance transaction is an agreement made between two parties called ceding company and reinsurer respectively, whereby the ceding company agrees to cede and the reisurer agrees accept the certain fixed of a risk upon terms as set out in the agreement. (p. 5)

Marianto (1997) also explained that the reinsurance from legal aspects is an agreement between an insurance operators with one or more insurers. Compulsory for insurance operators provide the reinsurance company to agree to be obliged to accept all or part of the risk assigned to it. Case as well as in insurance, reinsurance agreements compensatory nature. This agreement raises the rights and obligations between the two parties. Therefore, the reinsurance company is also entitled to receive all or part of the premiums received by the insurance operator based on the insurance policy have been issued.

This means that the source of law referring to in the conduct of reinsurance is the law and the law of the place in accordance to the local laws.

\section{Comparions Between Retakaful and Reinsurance}

Based on the studies in this paper, finding comparisons between retakaful and conventional reinsurance, following the similarities and differences, are as follows.

\section{Similarities}

Retakaful and conventional reinsurance discuss that the financial protection system is necessary by takaful operators and insurance operators involving takaful products and insurance products have high-risk and are likely to cause damage, destruction, and loss. This has the same purpose of providing financial protection against the risk of large losses. Risks governed derived from takaful and insurance products. Considering operated protection of risks, then made the security oriented. So, takaful products/insurance have risk and are protected, will be protected again so that can reduce the risk in the event of disaster struck.

Methods of risk arrangements use the same method that is known to facultative and treaty. The choice of this method depends on the needs of the risks incurred by looking at the financial funds which serve as protection. 


\section{Differences}

Retakaful mechanism has a very noticeable difference with reinsurance mechanism in various aspects. Starting from contract of transactions until the mechanism has been applied in the industry. This can be seen in Table 1.

Table 1

Differences Between Retakaful and Reinsurance

\begin{tabular}{lll}
\hline Aspect & Retakaful & Reinsurans \\
\hline Law sources & Islamic law & Civil law \\
Status of Sharia law & Lawful & Unlawful \\
Contract & Cooperation & Commercial \\
Model of payment & Contribution & Premium \\
Risk mechanism & Share & Transfer \\
Operator & Participant & Consumer \\
\hline
\end{tabular}

Based on Table 1, we can found that in terms of legal resources, retakaful mechanism refers to the principles of Islamic law, such as the Quran, hadith, fiqh methods, history, books of fiqh and scholars gathering results. Retakaful sector is one of the areas of transactions (muamalah), which must refer to Islam as a source of Islamic law. This emphasis on the Islamic position plays a very important role in monitoring and evaluating the running of retakaful. In addition, all transactions involving retakaful mechanism must always be under the supervision and evaluation of sharia. Meanwhile, reinsurance mechanism is referring to the civil law, made by humans. In other words, reinsurance is not applied by Islamic sharia law.

In contract terms, retakaful is used on the basis of tabarru/contribution as contract basis. By using the basic principles of sharia will be born naturally to help one another through the contributions of the participants. While reinsurance contract is a contract of protection policies purchase of insurance companies products against risks in a given time. If there is a great risk that would benefit the operator's insurance, reinsurance companies may be lost, because the premiums are not sufficient to pay the claims. If Premium excess money without risk whatsoever, then the profits belong to the company (reinsurance).

Retakaful committed to contribute to the surplus of the takaful operator funds. While conventional reinsurance fixed on some of the surplus.

Handling risks mechanism for retakaful is shared jointly by the takaful operator and managed by the retakaful operator/retakaful company. While reinsurance, risk is transferred from the insurance company to reinsurers and risk assumed responsibility in whole or in reinsurance companies.

Financial protection fee collected in retakaful system referred to as contributions paid by takaful operator. Thus, the takaful operators are contributors/participants of retakaful. While financial protection payments have been collected in the system of reinsurance is referred to as premiums paid to reinsurers customers.

\section{Conclusions}

Retakaful in the takaful industry are prescribed based on the derived istinbat evidences of Islamic law. Retakaful method is needed to protect high-value takaful products and may be exposed to high risks that exceed the retention limited through the sharing of risk between the takaful operators. The mechanism of retakaful is very different with reinsurance mechanism in terms of resources law, legal status, type of contract, payment models, risk regulation system, and the operating system. The takaful operators shall participate of retakaful and support services that can lead to the success of the takaful industry in the future. 


\section{References}

al-Bukhari, M. I. (1987). The Book of Prophet's Muhammad (pbub) sayings and deeds aunthenticated by Bukhari (Sahih Bukhari). Beirut: Dar Ibn Kathir al-Yamamah.

al-Qurrahdagi, A. M. A. (2005). Islamic insurance (al-Ta'min al-Islami). Beirut: Darol-Basha'ir al-Islamiyyah.

al-Qurtubi, M. A. (2000). The conpendium of legal rulings of the Qur'an (al-Jami 'cli Ahkam al-Quran). Beirut: House of Scintific Books (Darol-Kotub al-Ilmiyyah).

al-Salus, A. A. (1998). Islamic economics and contemporary jurisprudential issues (al-Iqtisad al-Islami wa al-Qadaya al-Fiqqiyyah al-Mu'asirah). Qatar: House of Culture (Dar al-Thaqafah) and (wa) Beirut: Foundation of Al Rayyan (Mu'assasah al-Rayyan).

al-Suyuti, J. A. (1998). al-Ashbah wa al-Nazair. Beirut: Darol-Kotub al-Ilmiyyah.

Cockerell, H. A. L. (1980). Insurance. London: Hodder Arnold H \& S.

Golding, C. E. (n.d.). The law and practice of reinsurance (p. 5). England: Buckley Press.

Hussin, M. Y. M. (2005). Retakaful concepts and operations in the insurance industry. Paper in Seminar: The Role of Takaful Industry in Economic Development in Malaysia (Konsep dan operasi retakaful dalam industry insurans. Kertas kerja seminar peranan industry takaful dalam pembangunan ekonomi di Malaysia). Universiti Malaya, Kuala Lumpur.

Islamic Banking and Finance Institute Malaysia (IBFIM). (2009). Takaful basic handbook (Asas Takaful, Buku Panduan). Kuala Lumpur: IBFIM.

Marianto, A. J. (1997). Reinsurance (Reasuransi). Jakarta: Ghalia Indonesia.

Muhammad, J., Redzuan, H., \& Said, R. M. (1995). Insurance for you (Insurans Untuk Anda). Shah Alam: Penerbit Fajar Bakti Sdn Bhd.

Muslihuddin, M. (1989). Insurance and Islamic law (Insurans dan Hukum Islam). Kuala Lumpur: Council of Language and Library (Dewan Bahasa dan Pustaka).

Muslim, A. H. (n.d.). The book of Prophet's Muhammad (pbub) Sayings and deeds aunthenticated by Muslim (Sahih Muslim). Beirut: Dar Ihya al-Turath.

Nyazee, I. A. K. (2004). Islamic jurisprudence. New Delhi: Adam Publishers \& Distributers.

Salamon, S. (1989). Islamic economics: Introduction and possibilities (Ekonomi Islam: Pengenalan dan Kemungkinan). Selangor: Dar al-Rahmaniyyah.

Sharafuddin, A. (1983). Insurance provisions in the law and the judiciary (Ahkam al-Ta'min fi al-Qanun wa al-Qada) (pp. 85-86). Kuwait: University of Kuwait (Jamiat al-Kuwait).

Sula, M. S. (2004). Sharia insurance (Asuransi Syariah). Jakarta: Gema Insani.

Yusof, M. F. (1996). Takaful islamic insurance system (Takaful Sistem Insurans Islam). Kuala Lumpur: Utusan Publications \& Distributors Sdn Bhd.

Yusof, M. F. (2006). Identifying takaful (Mengenal Takaful). Selangor, Malaysia: Ibs Buku Sdn Bhd. 